\title{
Simultaneous Detection of Colletotrichum
} acutatum and C. gloeosporioides from Quiescently Infected Strawberry Foliage by Real-Time PCR Based on High Resolution Melt Curve Analysis

\author{
Mahfuz Rahman"1,2*, Tofazzal Islam,4, Rosemary Schwegel1, Frank J. Louws 1,5 \\ ${ }^{1}$ Department of Plant Pathology, North Carolina State University, Raleigh, USA \\ ${ }^{2}$ WVU Extension Service, Morgantown, USA \\ ${ }^{3}$ Davis College of Agriculture Natural Resources and Design, West Virginia University, Morgantown, USA \\ ${ }^{4}$ Department of Biotechnology, Bangabandhu Sheikh Mujibur Rahman Agricultural University, Gazipur, Bangladesh \\ ${ }^{5}$ Department of Horticultural Science, North Carolina State University, Raleigh, USA \\ Email: *mm.rahman@mail.wvu.edu
}

How to cite this paper: Rahman, M., Islam, T., Schwegel, R. and Louws, F.J. (2019) Simultaneous Detection of Colletotrichum acutatum and C. gloeosporioides from Quiescently Infected Strawberry Foliage by RealTime PCR Based on High Resolution Melt Curve Analysis. American Journal of Plant Sciences, 10, 382-401.

https://doi.org/10.4236/ajps.2019.103028

Received: January 30, 2019

Accepted: March 8, 2019

Published: March 11, 2019

Copyright (๑) 2019 by author(s) and Scientific Research Publishing Inc. This work is licensed under the Creative Commons Attribution International License (CC BY 4.0).

http://creativecommons.org/licenses/by/4.0/

\begin{abstract}
Anthracnose of strawberry, caused primarily by the fungal pathogens belonging to Colletotrichum acutatum species complex (CASC) and C. gloeosporioides species complex (CGSC) is an economically important disease in the Southeast United States. Quiescently infected (QI) planting stock is one of the most important sources of inoculum in the fruiting field that can only be reliably detected by highly sensitive real time quantitative PCR (q-PCR) assay. In this study, a q-PCR assay was developed and optimized that can discriminate anthracnose fruit rot (AFR) and anthracnose crown rot (ACR) causing species based on the difference in post PCR melting temperatures of amplicons. Controlled environment grown plants artificially inoculated with different levels of $C A S C$ and $C G S C$ showed a significant $(P<0.001)$ correlation with levels of quantification expressed by $C_{t}$ values in q-PCR from petioles and leaf blades. The leaf blade was a significantly larger reservoir of QI than that of the petiole. Both TaqMan and SYBR Green assay showed similar sensitivity and specificity. Detection of QI on leaves at young middle and older stages from inoculation with same number of conidia indicated that middle aged leaves were the best for assessing QI. Quantification of QI from middle aged leaf samples from a strawberry fruiting field that has been planted with pre-inoculated plants at both ends of rows and let inoculum spread showed higher sensitivity and precision by q-PCR compared to that of a traditional
\end{abstract}


paraquat assay. The assay developed and validated in this study offers a new tool for evaluating planting stocks for QI to make decision on preventative control for strawberry anthracnose.

\section{Keywords}

Anthracnose, q-PCR, Quiescent Infection, Disease Prevention, Diagnostics

\section{Introduction}

The devastating losses caused by anthracnose fruit rot (AFR) and crown rot (ACR), in combination with the regional conducive weather and susceptibility of the current favored cultivars, make it one of the most economically important diseases of strawberry in the Southeast United States (SE) [1] [2]. If inoculum is present on foliage as quiescent infections (QI) and favorable weather conditions follow, brown or black sunken lesions appear on the berries (AFR) that render them unmarketable and can cause a yield loss of over $50 \%$ even under the most stringent management programs [1]. In contrast, ACR can kill a whole strawberry plant by aggressively invading and producing a reddish-brown to marbled orange necrosis of the crown tissue that causes the plant to wilt and collapse [3]. Although both Colletotrichum acutatum species complex (CASC) and C. gloeosporioides species complex (CGSC) can infect all parts of a strawberry plant, fruit rot is the major loss manifested by CASC infection, while crown rot and plant wilting are from $C G S C$. Inoculum sources for fruiting fields may be diverse but non-symptomatic infected planting stock is the most important [4] [5] [6] [7]. Contaminated planting stock is not symptomatic at lower level of infection [8] [9], and this can lead to the inadvertent introduction of the pathogen(s) to the fruiting field, a major challenge for fruit growers [6] [10] [11]. However, this contamination can be prevented with a highly sensitive DNA based diagnostic tool. Assessing the levels of QI and defining the parameters that lead to inoculum multiplication in the field can foreseeably be used in risk assessment tools for anthracnose outbreaks and provide growers crucial information to make management decisions. Current methods for detecting QI rely primarily on either of the following bioassay techniques: surface sterilized foliage is killed by dipping in herbicide gramoxone (Paraquat), ethanol immersion or by freezing followed by incubating senesced foliage inside a humid chamber to enhance sporulation and the tissue surface is then evaluated for the presence of the pathogen [11] [12]. The primary disadvantage of these assays is that they rely on the sporulation of the pathogen. The tissue samples are generally incubated for 7 to 10 days to allow for sufficient acervular growth to be visible [10] [12], which results in a time-consuming assay. Also, sporulation may be inhibited [10] by previously applied fungicides or by the surface disinfestations common to these assays, thus creating a potential for false negatives. However, if the disinfestation 
steps were to be removed, the growth of contaminating organisms such as Botrytis, Gnomonia, or Phomopsis would obscure the results. Sequence comparison by polymerase chain reaction (PCR) [13] [14] [15] [16], arbitrarily-primed PCR [17], isozyme comparisons [18], and restriction fragment length polymorphism (RFLP) analysis [19] [20] and DNA fingerprinting by random amplification of polymorphic DNA (RAPD) [20] [21] [22] have all been used for detection and differentiation of the Colletotrichum species. Most of these techniques were primarily designed for taxonomic studies, but Sreenivasaprasad et al. [16] and Parikka and Lemmetty [9] designed PCR assays for the detection of $C$. acutatum on strawberry. These assays have proven to be specific, and more rapid than the bio-amplification-type assays [9] [16].

Real-time PCR offers greater potential for sensitivity and specificity than conventional PCR for detecting and quantifying very low level of infection. Debode et al. [23] developed q-PCR protocol and investigated latent entry of CASC only, which is a major problem in Europe but in the SE both CASC and CGSC are major concerns. These pathogenic variabilities and genetic diversities were partly revealed in previous studies [24]. Among the available real time PCR assays, 5' nuclease-based TaqMan assay is considered superior over the SYBR green based assay as TaqMan assay increases specificity because of the fluorescent probe. However, TaqMan assay is often considered prohibitively expensive for commercial assay. Assays based on a relatively inexpensive dye SYBR green can be used for routine assay if they produce comparable results in a specific reaction condition. Tian et al. [25] reported that SYBR green did not show similar sensitivity, specificity, accuracy, and reproducibility as the TaqMan or Molecular beacon did, but Bilodeau et al. [26] used TaqMan, SYBR Green and molecular beacons for the quantification of Phytophthora ramorum based on $\beta$-tubulin gene and obtained comparable Ct values of 22.04, 22.77 and 25.08, respectively. Thus, selection of protocols for a routine assay should be considered on a case-by-case basis. Some other relevant studies designed $C$. acutatum species specific primers and probe set that work well with crown or petiole tissue but tended to lose sensitivity with leaf tissues [23] [27]. The primers and probe sets designed by these authors were not tested with low cost detection assay such as SYBR green and did not attempt to quantify both $C A S C$ and $C G S C$ simultaneously.

Transplant nurseries in NC revealed the occurrence of both $C$. acutatum and C. gloeosporioides QI on foliage that was implicated with major fruiting field devastation in recent years ([28], Barclay Poling, SE strawberry council advisor, personal communication] as QI escaped visual inspection. Inspection protocol for this kind of situations inevitably requires special DNA based sensitive tool capable of simultaneous detection of $C$. acutatum and $C$. gloeosporioides from QI. One strategy by which the full potential of PCR might be realized in case of the presence of multiple species/strains of pathogen is multiplexing or their discrimination based on high resolution melt curve analysis of amplicons [29] [30]. In a strawberry nursery or fruiting field situation, petioles are normally hidden 
underneath the leaf blades, providing petioles less exposure to oncoming inocula. However, our field observations indicated that necrotic symptoms are sometimes visible on petioles but not on leaf blades. This observation however, doesn't support the hypothesis of petiole being the larger reservoir for Colletotrichum inoculum or vice versa as quiescence may be differentially regulated in different tissue types. The objectives of this study were to: 1) design quantitative real time PCR (q-PCR) assays to specifically detect Colletotrichum spp., based on two reporter technologies (SYBR Green and TaqMan probes) targeting the ITS region and discriminate them by utilizing high resolution melt curve analysis; 2) validate the real-time PCR assays using DNA from pure cultures of a collection of Colletotrichum spp. and from quiescently infected plant samples such as petiole and leaf blade; 3 ) identify the best tissue type and optimize the tool for detecting QI from strawberry field. Preliminary report from this research has been published [31] [32].

\section{Materials and Methods}

\subsection{Design of a Colletotrichum-Specific Primer/Probe Set}

A consensus sequence was developed from $42 C A S C$ and $C G S C D N A$ sequences of the ITS1-5.8S rDNA-ITS2 region obtained from the EMBL Nucleotide Sequence Database (Table 1). Beacon Designer software (Premier Biosoft, Palo Alto, CA) was used to design a dual-labeled TaqMan probe and multiple primer sets from the consensus sequence. The probe was labeled with reporter dye 6-caboxyfluorescein (6-FAM) at the 5' end and quencher dye 6-Carboxytetramethylrhodamine (6-TAMRA) at 3 ' end. The primer/probe set developed was in the ITS2 region to produce amplicon sizes as shown in Table 2 . The target region had multiple single nucleotide polymorphic sites and a deletion site on CASC sequence (Figure 1). Discrimination of CASC and CGSC was done based on these differences.

\subsection{Primer/Probe Specificity Testing}

A basic local alignment search tool (BLAST) was utilized to search for matches to the primers and probe sequences against the NCBI GenBank database (http://www.ncbi.nlm.nih.gov/BLAST) to ensure the specificity of the primers and probes prior to synthesis by Applied Biosystems (ABI-Foster City, CA). Additional primer/probe specificity was evaluated using pure cultures of isolates of C. acutatum, and C. gloeosporioides obtained from the North Carolina State University (NCSU) Plant Disease and Insect Clinic (PDIC) and from Dr. Stanley Freeman of the Volcani Center in Israel. Specificity was also evaluated for other fungal species isolated from strawberry by the NCSU-PDIC, including Fusarium oxysporum, F. solani, Phytophthora cactorum, Pythium irregulare, P. ultimum, P. dissotocum, Rhizoctonia fragariae, Botrytis cinerea, Phomopsis obscurans, Mycosphaerella fragariae, Diplocarpon earliana, and Gnomonia comariae. Genomic DNA extracted by Qiagen DNA extraction kit (Valencia, CA 91355) from 
Table 1. DNA sequences used for the design of a TaqMan primer/probe set for the detection of Colletotrichum spp. by real-time $\mathrm{PCR}^{\mathrm{z}}$.

\begin{tabular}{|c|c|c|c|c|}
\hline EMBL acc \# & Organism & Reference & Host & Origin \\
\hline AF272780 & G. cingulata & Freeman et al. 2001 & Strawberry & United States \\
\hline AF272784 & G. acutata & Freeman et al. 2001 & Strawberry & United States \\
\hline AF272785 & G. acutata & Freeman et al. 2001 & Strawberry & France \\
\hline AF272789 & G. acutata & Freeman et al. 2001 & Strawberry & Spain \\
\hline AF489556 & G. acutata & Denoyes-Rothan et al. 2003 & Raspberry & United States \\
\hline AF489557 & G. acutata & Denoyes-Rothan et al. 2003 & Strawberry & Switzerland \\
\hline AF489558 & G. acutata & Denoyes-Rothan et al. 2003 & Strawberry & United States \\
\hline AF489559 & G. acutata & Denoyes-Rothan et al. 2003 & Grape & United States \\
\hline AF489560 & G. acutata & Denoyes-Rothan et al. 2003 & Tomato & United States \\
\hline AF489561 & G. acutata & Denoyes-Rothan et al. 2003 & Strawberry & France \\
\hline AF489562 & G. acutata & Denoyes-Rothan et al. 2003 & Strawberry & France \\
\hline AF489563 & G. acutata & Denoyes-Rothan et al. 2003 & Blackberry & Switzerland \\
\hline AF489564 & G. acutata & Denoyes-Rothan et al. 2003 & Strawberry & France \\
\hline AF489565 & G. acutata & Denoyes-Rothan et al. 2003 & Tomato & United States \\
\hline AF489566 & G. acutata & Denoyes-Rothan et al. 2003 & Strawberry & France \\
\hline AF489567 & G. acutata & Denoyes-Rothan et al. 2003 & Bilberry & France \\
\hline AF489568 & G. cingulata & Denoyes-Rothan et al. 2003 & Strawberry & Spain \\
\hline AJ536199 & G. acutata & Martinez-Culebras et al. 2003 & Strawberry & France \\
\hline AJ536200 & G. acutata & Martinez-Culebras et al. 2003 & Strawberry & United States \\
\hline AJ536201 & G. acutata & Martinez-Culebras et al. 2003 & Strawberry & Switzerland \\
\hline AJ536202 & G. acutata & Martinez-Culebras et al. 2003 & Strawberry & United States \\
\hline AJ536203 & G. acutata & Martinez-Culebras et al. 2003 & Strawberry & Costa Rica \\
\hline AJ536204 & G. acutata & Martinez-Culebras et al. 2003 & Strawberry & U.K. \\
\hline AJ536205 & G. acutata & Martinez-Culebras et al. 2003 & Strawberry & Japan \\
\hline AJ536206 & G. acutata & Martinez-Culebras et al. 2003 & Strawberry & Australia \\
\hline AJ536207 & G. acutata & Martinez-Culebras et al. 2003 & Strawberry & Australia \\
\hline AJ536208 & G. acutata & Martinez-Culebras et al. 2003 & Strawberry & Australia \\
\hline AJ536209 & G. acutata & Martinez-Culebras et al. 2003 & Strawberry & Spain \\
\hline AJ536210 & G. acutata & Martinez-Culebras et al. 2003 & Strawberry & Netherlands \\
\hline AJ536211 & G. acutata & Martinez-Culebras et al. 2003 & Strawberry & U.K. \\
\hline AJ536212 & G. acutata & Martinez-Culebras et al. 2003 & Strawberry & New Zealand \\
\hline AJ536213 & G. acutata & Martinez-Culebras et al. 2003 & Strawberry & New Zealand \\
\hline AJ536214 & G. acutata & Martinez-Culebras et al. 2003 & Strawberry & United States \\
\hline AJ536215 & G. acutata & Martinez-Culebras et al. 2003 & Strawberry & New Zealand \\
\hline AJ536216 & G. acutata & Martinez-Culebras et al. 2003 & Strawberry & New Zealand \\
\hline AJ536217 & G. acutata & Martinez-Culebras et al. 2003 & Strawberry & France \\
\hline AJ536218 & G. acutata & Martinez-Culebras et al. 2003 & Strawberry & France \\
\hline AJ536219 & G. acutata & Martinez-Culebras et al. 2003 & Strawberry & New Zealand \\
\hline AJ536220 & G. acutata & Martinez-Culebras et al. 2003 & Strawberry & France \\
\hline AJ536224 & G. cingulata & Martinez-Culebras et al. 2003 & Strawberry & Canada \\
\hline AJ536225 & G. cingulata & Martinez-Culebras et al. 2003 & Strawberry & United States \\
\hline AJ536226 & G. cingulata & Martinez-Culebras et al. 2003 & Strawberry & United States \\
\hline
\end{tabular}

${ }^{z}$ Sequence data was obtained from the EMBL Nucleotide Sequence Database (http://www.ebi.ac.uk/embl/). 
Table 2. TaqMan primer/probe set designed for real-time PCR detection of Colletotrichum spp. ${ }^{\mathrm{a}}$.

\begin{tabular}{clcc}
\hline Oligonucleotide & \multicolumn{1}{c}{ Sequence (5' to 3') } & $\begin{array}{c}\text { Length } \\
\text { (bp) }\end{array}$ & $\begin{array}{c}\text { Amplicon length } \\
\text { (DMT) }^{\mathrm{b}}\end{array}$ \\
\hline${ }^{\mathrm{x}}$ Sense (ColTqF1) & GGCCCTTAAAGGTAGTGGCG & 20 & $95(0)$ \\
${ }^{\mathrm{x}}$ Sense (ColTqF2) & GCTTGGTGTTGGGGCCC & 17 & $127(1.1)$ \\
${ }^{\mathrm{x}}$ Sense (ColTqF3) & GCTTGGTGTTGGGGCCCTAC & 20 & $127(0.6)$ \\
${ }^{\mathrm{y}}$ Anti-sense (ColTqR1) & GGTTTTACGGCAAGAGTCCCT & 21 & - \\
${ }^{2}$ Probe (ColTqP1) & CCCTCCCGGAGCCTCCTTTGCGTA & 24 & - \\
\hline
\end{tabular}

${ }^{\text {aS }}$ equence data from Table 1 was used to develop a consensus sequence using MegAlign software. The primer/probe set and was designed from the consensus sequence using Beacon Designer software. ${ }^{\text {b} D M T-D i f f e r e n c e ~ i n ~ m e l t i n g ~ t e m p e r a t u r e ~ o f ~ a m p l i c o n s ~ f r o m ~ C . ~ a c u t a t u m ~ a n d ~ C . ~ g l o e o s p o r i o i d e s ~ t e m p l a t e ~}$ when reverse primer was used with different combinations of forward primers. ${ }^{x}$ forward primers; ${ }^{\mathrm{y}}$ reverse primer; ${ }^{\mathrm{T} T a q m q n}$ probe

gl GCTTGGTGTTGGGGCCCTACAGCTGATGTAGGCCCTCAAAGGTAGTGGCGGACCCTCCCG ac GCTTGGTTTTGGGGCCCCACGGCCGACGTGGGCCCTTAAAGGTAGTGGCGGACCCTCCCG gl GAGCCTCCTTTGCGTAGTAACTTTACGTCTCGCACTGGGATCCGGAGGGACTCTTGCCGT ac GAGCCTCCTTTGCGTAGTAACT-AACGTCTCGCACTGGGATCCGGAGGGACTCTTGCCGT gl AAAACC

ac TAAACC

Figure 1. DNA sequence alignment of the internal transcribed spacer-2 region from $C$. gloeosporioides and $C$. acutatum species complex showing the q-PCR amplicons, and positions of polymorphic differences used to discriminate species complex by high resolution melt curve (HRM) curve analysis; ac, C. acutatum species complex (CASC); gl, C. gloeosporioides species complex (CGSC).

each fungal isolate $\left(\approx 2.5 \mathrm{ng} \cdot \mathrm{\mu l}^{-1}\right)$ was used as template, and amplification was performed in ABI Prism 7900 HT Sequence Detection System using the default thermal cycling assay, $95^{\circ} \mathrm{C}$ for $10 \mathrm{~min}$ for activation of AmpliTaq Gold DNA polymerase, and 40 cycles of $95^{\circ} \mathrm{C}$ for $15 \mathrm{~s}$ for template denaturation and $60^{\circ} \mathrm{C}$ for $1 \mathrm{~min}$ for annealing and elongation. A baseline of 30 fluorescence units was set as the background threshold, and reactions in which FAM or SYBR based fluorescence exceeded this value were considered positive for $C$. acutatum and C. gloeosporioides. Cycle threshold $\left(\mathrm{C}_{\mathrm{t}}\right)$ values (PCR cycle number at which fluorescence exceeded the detection threshold) were recorded for each reaction. The reactions were performed at a volume of $25 \mu \mathrm{l}(2.5 \mu \mathrm{l}$ of DNA in $22.55 \mu \mathrm{l}$ master mix). Primer concentration was optimized at $300 \mathrm{nM}$ and probe concentration at $200 \mathrm{nM}$. All supplies (primers, probe, TaqMan Universal PCR Master Mix, MicroAmp optical 8-tube strips and Power SYBR) were obtained from ABI.

\subsection{Species Discrimination}

Different forward primers were tested in combination with a conserved reverse primer to produce amplicons of different sizes in q-PCR. Forward primers located upstream of the single nucleotide polymorphic (SNP) sites were selected for this study that provided a net plus of more than $1^{\circ} \mathrm{C}$ in post PCR melting temperature for amplicons produced from $C$. acutatum template DNA compared to amplicons from C. gloeosporioides (Figure 2). Amplicon sequences 


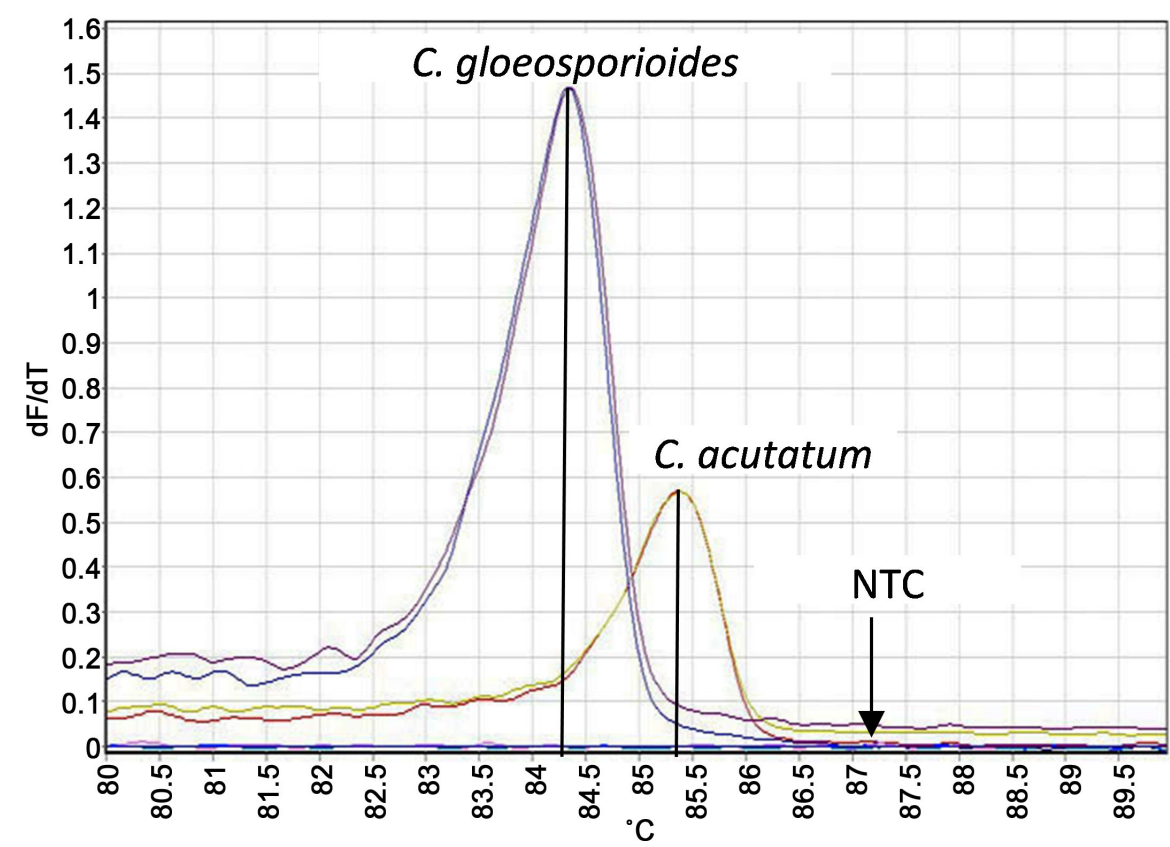

Figure 2. High resolution melt curve analysis of amplicons from C.gloeosporioides and C. acutatum DNA extracts by using Evagreen dye present in Type-it HRM PCR kit; melting temperature has $>1{ }^{\circ} \mathrm{C}$ difference between CASC and CGSC that can indicate presence of both or either of the species complex in the sample from where DNA was extracted.

were aligned with online version of CLUSTALW (http://align.genome.jp/). Following a final extension at $60^{\circ} \mathrm{C}$ for $1 \mathrm{~min}$, melt curves were generated using the default settings in high resolution melt (HRM) in a QIAGEN Rotor-Gene Q (Corbett Rotor-Gene 6000, Valencia, CA 91355) using Type-it HRM PCR kit (Qiagen, Valencia, CA 91355). This experiment was done twice.

\subsection{Standard Development for C. acutatum and C. gloeosporioides}

To determine the amplification efficiency of a specific primer set in TaqMan assay, 10-fold serial dilutions of pure genomic DNA were generated ranging from $25 \mathrm{ng} \cdot \mathrm{\mu l}^{-1}$ to $25 \mathrm{fg} \cdot \mathrm{\mu l}^{-1}$ in sterile deionized distilled water $\left(\mathrm{sddH}_{2} \mathrm{O}\right)$. Genomic DNA was extracted as described above and quantified using a NanoDrop spectrophotometer (NanoDrop Technologies, Inc., Wilmington, DE). Then $\mathrm{C}_{\mathrm{t}}$ values were generated for each dilution of $C$. acutatum and C. gloeosporioides genomic DNA in four replicates for TaqMan assay separately. A standard curve was obtained by plotting mean $\mathrm{C}_{\mathrm{t}}$ values against $\log _{10} \mathrm{DNA}$ concentrations. Linear regression analysis was conducted on the data, and the slope of the regression line was used to estimate amplification efficiency according to the following formula $\mathrm{E}_{\mathrm{x}}=\left(10^{(-1 / m)}-1\right) * 100$, where $\mathrm{E}_{\mathrm{x}}$ is the amplification efficiency and $m$ is the slope of the standard curve [33].

\subsection{Effect of Host Metabolite on PCR Efficiency}

C. acutatum and C. gloeosporioides conidia were produced in potato dextrose 
agar (PDA) plates. Conidial suspensions from different petri plates were combined, counted using a hemocytometer to have 100,000 conidia each in two replicates. Conidial suspension was centrifuged at a speed of $12,000 \mathrm{~g}$ to form a pellet at the bottom of the tube. Supernatant was decanted, and conidial pellets were frozen by liquid $\mathrm{N}_{2}$ as pure or by mixing $50 \mathrm{mg}$ leaf tissue and DNA extracted with Qiagen DNeasy Plant mini kit (Valencia, CA 91355). Initial template concentration was used to create a $10^{6}-10^{1}$ standard curve by a 1:10 dilution series for both extracts. This experiment was conducted twice.

\subsection{Identification of Leaf Stage Supporting Highest Detection and Quantification}

For a preplanned inoculation and sampling, leaves from 8 replicate greenhouse-grown plants were selected to represent 3 different growth stages such as young (fully opened), middle age ( $\sim 30$ days after full opening) and old ( $\sim 0$ days or older after full opening). Conidia were produced using the same isolates and method mentioned above. Leaves were inoculated with 5 different concentrations $(10,20,50,500$, and 1000 conidia) by placing $10 \mu \mathrm{l}$ conidial suspension droplets on pre-marked areas. Immediately after inoculation, plants were covered with plastic bags for $72 \mathrm{~h}$ after which time leaves were sampled by cutting leaf disks with a scissors from the inoculation sites. Direct DNA extraction and q-PCR of four replicate samples $(50 \mathrm{mg}$ each) for each conidial concentration was performed following default cycle parameter mentioned before. Real time PCR cycle was also run with SYBR Green for extracts from each sample following the same cycle parameter with melting temperature of amplicons to ensure non-specific amplification did not occur. To maintain equal number of samples and tissue amount for comparing by PCR and bioassay, only pre-selected areas were evaluated.

\subsection{Assessment of Petiole and Leaf Blade for Potential Reservoir of Quiescent Infections}

This experiment was conducted under both field and greenhouse conditions.

\subsubsection{Field Experiment}

Leaf blades were sampled from a field experiment conducted at the Horticultural Crops Research Station in Castle Hayne, NC. Rooted plug plants were planted in standard fumigated raised plastic mulched beds on $1.5-\mathrm{m}$ centers, $15-\mathrm{cm}$. high, $68.5-\mathrm{cm}$. wide, and arranged in a randomized complete block design (RCBD) with four replications. Highly AFR susceptible "Chandler" plug plants were inoculated with $5 \times 10^{5}$ conidia $\cdot \mathrm{ml}^{-1}$ (equally mixed using 4 CASC and CGSC single-conidia strains, JVL7-01, JCP7-02 and PDIC7-745, PDIC-750) by spraying on the foliage up to run off followed by incubation in a humid chamber for $48 \mathrm{~h}$ at ambient room temperature $\left(21^{\circ} \mathrm{C} \pm 2^{\circ} \mathrm{C}\right)$. Two of these inoculated plants were then planted at both ends of each $8 \mathrm{~m}$ field plot to allow "natural" spread of inoculum throughout the growing season. Immediately after transplanting plants 
were overhead irrigated with sprinklers for 3 days ( 5,3 and $2 \mathrm{~h}$, respectively) to aid plant establishment. Commercially recommended pre-plant fertilization and other cultural practices were followed. All other irrigation and fertilization was done through the drip tape that was pre-set at the middle during bed formation. No fungicides were applied during the growing season. Leaf and petiole samples from randomly selected plants at each distance from the point of inoculation ( 0 , 1, 2, 3, 4 m) 40 replicate plots were collected at 60 days after planting. From each trifoliate leaf sample, one randomly selected leaflet and half petiole were used for DNA extraction and the rest for paraquat assay (induction of senescence to surface sterilized leaves/petioles by dipping in paraquat followed by a short incubation on metal screens inside a humid chamber layered with moist paper towel to enhance acervular growth). Samples were bulked for Colletotrichum incidence assay and comparison of petiole and leaf blade from directly inoculated plants. However, dispersal severity and comparison of methods were performed from only leaf blades of samples that were kept separate based on distance from point of inoculation.

\subsubsection{Phytotron Experiment}

Sixty strawberry plug plants of 'Chandler' were obtained from the NCSU Micropropagation Unit and Repository (MPUR) and transferred to the Phytotron growth chambers. Forty plants were placed in each of two $3 \mathrm{~m}^{2}$ walk-in growth chambers set at $26 / 22^{\circ} \mathrm{C}$ day/night temperatures under $14 \mathrm{~h}$ of fluorescent light to suppress flowering and encourage vegetative growth. The plants were then spray-inoculated with conidial suspension as mentioned above and covered with clear plastic for 48 hours to maintain high humidity. One set of 60 leaves and petioles (one from each plant) were collected 60 days after inoculation and processed as described before for evaluating the relative incidence. The whole experiment was conducted in the greenhouse twice by another set of sixty plants. In both phytotron and field experiments, samples that were used for q-PCR were immediately frozen in liquid nitrogen and kept frozen at $-80^{\circ} \mathrm{C}$ freezer until DNA extraction. Samples for paraquat assay were processed immediately.

\subsection{Statistical Analysis}

Cycle threshold $\left(\mathrm{C}_{\mathrm{t}}\right)$ values obtained from five different conidial concentrations at three different leaf stages and two different q-PCR protocols were subjected to factorial analysis of variance (ANOVA) using the general linear models procedure (PROC GLM) of the statistical analysis system (SAS 9.2, SAS Institute Inc., Cary, NC). Fisher's protected least significant difference (LSD) test $(P=0.05)$ was used to compare individual $\mathrm{C}_{\mathrm{t}}$ means at each spore concentration and leaf stage and estimate standard errors of means. For the dispersal study in the strawberry field, any sample showed $C_{t}$ values within the detection limit of 40 was considered to have received inoculum from the point of inoculation/source or due to secondary spread from the non-inoculated plants. Quiescent infection incidence was calculated from the ratio of positive q-PCR detection out of total 
number of samples collected at each sampling distance. Regression analysis of quiescent infection severity by paraquat method and q-PCR with distance from inoculation point was performed in SAS to determine and compare the efficacy of methods for detecting QI on strawberry foliage.

\section{Results}

\subsection{Primer/Probe Specificity Testing}

The q-PCR primer/probe sets were found to amplify all CASC and CGSC isolates tested (Table 3). Forward primer 1 (ColTqF1) with reverse primer and TaqMan probe was found highly specific to these fungal isolates due to additional specificity provided by probe sequences. ColTqF1 with ColTqR1 showed slightly lower specificity in SYBR green protocol, but both systems showed statistically similar amplification efficiency. However, this pair of primers did not prove useful for discriminating $C A S C$ and $C G S C$ as there was no difference in melting temperature of amplicons. ColTqF2 and ColTqF3 with ColTqR1 were useful in discriminating these two species of Colletotrichum with $0.6^{\circ} \mathrm{C}$ and $1.1^{\circ} \mathrm{C}$ differences in melting temperature, respectively. The BLAST search found matches for the primer/probe set with a few Colletotrichum species such as $C$. viniferum and $C$. musae that are not considered strawberry pathogens or cause quiescent infections on strawberry foliage.

Table 3. Fungal species used to test the specificity of the TaqMan primer/probe set for q-PCR detection of Colletotrichum spp. ${ }^{\mathrm{y}, \mathrm{z}}$.

\begin{tabular}{|c|c|c|c|}
\hline Species & Isolate & Source & $\begin{array}{l}\text { Real-time PCR } \\
\text { Amplification }\end{array}$ \\
\hline Colletotrichum acutatum & $\mathrm{Ca} 29$ & S. Freeman y & + \\
\hline Colletotrichum acutatum & 01-1218 & NCSU PDIC ${ }^{z}$ & + \\
\hline Colletotrichum acutatum & 01-1601 & NCSU PDIC ${ }^{z}$ & + \\
\hline Colletotrichum acutatum & 01-1608 & NCSU PDIC ${ }^{z}$ & + \\
\hline Colletotrichum gloeosporioides & Cg163b & S. Freeman ${ }^{y}$ & + \\
\hline Colletotrichum gloeosporioides & $\operatorname{Cg} 272 a$ & S. Freeman ${ }^{y}$ & + \\
\hline Fusarium oxysporum & B104 & NCSU PDIC ${ }^{z}$ & - \\
\hline Fusarium solani & $\mathrm{V} 2 \mathrm{AB}$ & NCSU PDIC ${ }^{z}$ & - \\
\hline Phytophthora cactorum & 03-3192 & NCSU PDIC ${ }^{z}$ & - \\
\hline Pythium dissotocum & C-11-D2 & NCSU PDIC ${ }^{z}$ & - \\
\hline Pythium irregulare & C-11-4P & NCSU PDIC & - \\
\hline Rhizoctonia fragariae & AGA-NS2 & NCSU PDIC ${ }^{\mathrm{z}}$ & - \\
\hline Gnomonia comari & $10-7197$ & NCSU PDIC & - \\
\hline Diplocarpon earlianum & $8-1064$ & NCSU PDIC ${ }^{z}$ & - \\
\hline Mycosphaerella fragariae & $10-7197$ & NCSU PDIC & - \\
\hline Phomopsis obscurans & $9-4005$ & NCSU PDIC & - \\
\hline
\end{tabular}

${ }^{y}$ Dr. Stanley Freeman, The Volcani Center, Bet Dagan, Israel; ${ }^{2}$ North Carolina State University Plant Disease and Insect Clinic, Raleigh, NC, USA. 


\subsection{Species Discrimination}

Amplicon sequences obtained by using $C$. acutatum and C. gloeosporioides templates in q-PCR reaction aligned with CLUSTALW showed several polymorphic differences (Figure 1) especially when ColTqF3 was used in combination with ColTqR1. The differences in target sequences accounted for a difference of $1.1^{\circ} \mathrm{C}$ in melting temperature providing the ability of discriminating two major anthracnose causing species of Colletotrichum. This difference in amplicon melting temperature alleviated the need for multiplexing. Post amplification high resolution melt (HRM) curve analysis revealed the melting temperature for C. gloeosporioides was 84.3 compared to 85.4 for $C$. acutatum (Figure 2) when Eva green was used as a $3^{\text {rd }}$ generation amplicon intercalating dye present in Type-it HRM PCR kit. Both experiments produced very similar melting curve providing support for reproducibility.

\subsection{Standard Development}

The goodness of fit ( $\mathrm{R}^{2}$ value) for standard curve was 0.9986 or better when DNA from both CASC and CGSC pure cultures were used, indicating a high reproducibility and accurate quantification (Figure 3 ). The amplification efficiency was decreased due to the addition of strawberry tissues with Colletotrichum conidia compared to conidia only indicating the presence of inhibitory metabolites in the tissue that reduced amplification efficiency from 0.9986 to 0.8639 or by $13.47 \%$. In spite of the presence of inhibitors, cycle threshold $\left(C_{t}\right)$ values showed linear relationship with concentration of the target DNA from Colletotrichum spp. pure culture or artificially inoculated leaves with known number of conidia, indicating that the method is suitable both as a qualitative and quantitative assay.

\subsection{Assessment of Petiole and Leaf Blade as a Potential Reservoir of Quiescent Infection}

Both bioassay and q-PCR clearly showed that leaf blades had remarkably higher

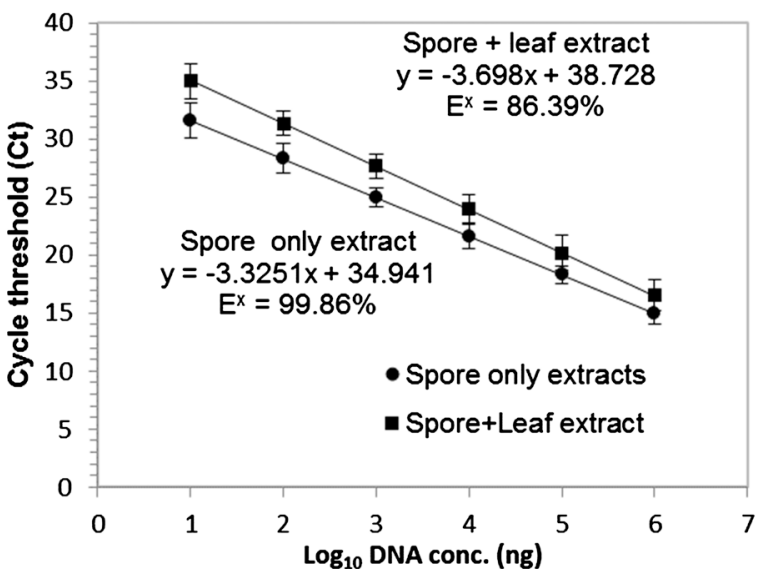

Figure 3. Real-time PCR amplification efficiency of DNA extract from pure culture conidia and conidia mixed with strawberry leaf tissue indicating the presence of PCR inhibitor in foliage tissue. Extraction kit such as quiagen however, can remove most of the inhibitors. 
inoculum compared to petiole in either directly inoculated plants in the phytotron greenhouse or natural spread of inoculum in the field from an initial inoculum source. In the phytotron/greenhouse $60.8 \%$ petiole showed positive detection compared to $89.2 \%$ in the leaf blades by q-PCR. Under the same phytotron conditions, only $36.5 \%$ petioles showed positive results compared to $65.3 \%$ leaf blades by paraquat assay. In field conditions, q-PCR detected Colletotrichum spp. on only $26.7 \%$ petiole compared to $52.8 \%$ leaf blades. Detection level by paraquat assay in the field was $17.1 \%$ on petiole compared to $31.4 \%$ on leaf blade (Table 4). Average detection of Colletotrichum spp. was $24 \%$ higher on leaf blade compared to petiole when both field and phytotron and methods of detection were considered. The margin was wider in the phytotron with $27 \%$ than in the field with $20.2 \%$. Besides being quantitative, q-PCR showed higher detection percentage in both petiole and leaf blades in the greenhouse and field conditions compared to a traditional paraquat protocol.

\subsection{Identification of Leaf Stage Supporting Highest Detection and Quantification}

Both leaf age and number of conidia placed on leaf surface significantly ( $P \leq$ 0.001) influenced detection of Colletotrichum spp. No leaf stage due to inoculation showed any disease symptom (black spot or necrosis) after $72 \mathrm{~h}$ of incubation at high humidity in the controlled environment of the greenhouse. Direct extraction of DNA from the middle-aged leaf tissue followed by q-PCR with either TaqMan or SYBR Green showed significant correlation of initial conidia number and $C_{t}$ values obtained. $C_{t}$ values from young leaf stage showed weaker

Table 4. Comparison of Colletotrichum spp. quiescent infection incidence (\%) detection through paraquat bioassay and real-time PCR from artificially inoculated strawberry leaves and petioles in phytotron/greenhouse and field conditions ${ }^{\mathrm{y}, \mathrm{z}}$.

\begin{tabular}{|c|c|c|c|c|c|c|}
\hline \multicolumn{7}{|c|}{ Phytotron/greenhouse ${ }^{\mathrm{y}}$} \\
\hline \multicolumn{4}{|c|}{ Petiole: $\mathrm{n}=120$} & \multicolumn{3}{|c|}{ Leaf: $n=120$} \\
\hline Assay method & Bioassay + & Bioassay - & SUM & Bioassay + & Bioassay - & SUM \\
\hline Real-time PCR + & 35.8 & 25.0 & 60.8 & 57.7 & 31.5 & 89.2 \\
\hline Real-time PCR - & 0.7 & 48.5 & 49.2 & 7.6 & 13.2 & 20.8 \\
\hline SUM & 36.5 & 63.5 & 100 & 65.3 & 44.7 & 100 \\
\hline \multicolumn{7}{|c|}{ Field $^{\mathrm{z}}$} \\
\hline \multicolumn{3}{|c|}{ Petiole: $\mathrm{n}=80$} & \multicolumn{4}{|c|}{ Leaf: $n=80$} \\
\hline Assay method & Bioassay + & Bioassay - & SUM & Bioassay + & Bioassay - & SUM \\
\hline Real-time PCR + & 11.5 & 15.2 & 26.7 & 29.6 & 23.2 & 52.8 \\
\hline Real-time PCR - & 5.6 & 67.7 & 73.3 & 1.8 & 45.4 & 47.2 \\
\hline SUM & 17.1 & 82.9 & 100 & 31.4 & 68.6 & 100 \\
\hline
\end{tabular}

${ }^{\mathrm{y}}$ Leaf and petiole samples were collected from the same plant and cut separated in the lab before processing. ${ }^{z}$ Data are means from 3 different samplings pooled together. ${ }^{\text {z }}$ Samples were collected from inside the plots that had inoculated plants at both ends and inoculum spread inside the plot occurred naturally. Data are means from 2 different samplings. 
correlation and higher variability among replicates with number of conidia placed on preselected leaf areas. Lower number of conidia placed on older leaves could not be detected with any of the q-PCR assays. Relatively high number of conidia (50 and above) were detected with TaqMan protocol at higher $\mathrm{C}_{\mathrm{t}}$ values and weaker correlation with increasing number of conidia. Lack of strong correlation of $C_{t}$ values with number of conidia or inability of detecting lower conidia number indicates that very young and old stages of leaf may be less suitable for quantification of inoculum load on foliage (Figure 4).

\subsection{Comparison of Real-Time PCR Efficiency in TaqMan and SYBR Green Technology}

Both TaqMan and SYBR Green assays were very efficient in detecting and quantifying $C A S C$ and $C G S C$ from foliar tissue. Both technologies produced almost identical mean cycle threshold when inoculum from known number of conidia were extracted and quantified separately by these methods. Similar results were obtained with samples collected from inoculated field plants. At very low inoculum levels, TaqMan assay showed higher sensitivity compared to SYBR green. Variation in cycle threshold values in TaqMan was less than SYBR among replicates and experiments (Figure 5). Data from only middle age leaf was used for this comparison. There was no statistical difference $(P>0.08)$ in the $\mathrm{Ct}$ values for both technologies. Melt curve analysis with SYBR green showed right temperature for $C$. gloeosporioides $\left(84.3^{\circ} \mathrm{C}\right)$ and $C$. acutatum $\left(85.4^{\circ} \mathrm{C}\right)$ indicating no primer dimer nor any non-specific amplifications. This result indicates that SYBR $^{\circledR}$ Green-based assay is as sensitive as the TaqMan ${ }^{\circledR}$ assay with these PCR primers if the right leaf stage is selected.

\subsection{Validation and Comparison of Colletotricum spp. Detection through Dispersal Study in the Strawberry Fruiting Field}

Neither inoculated nor plants at a distance that received inoculum due to a natural

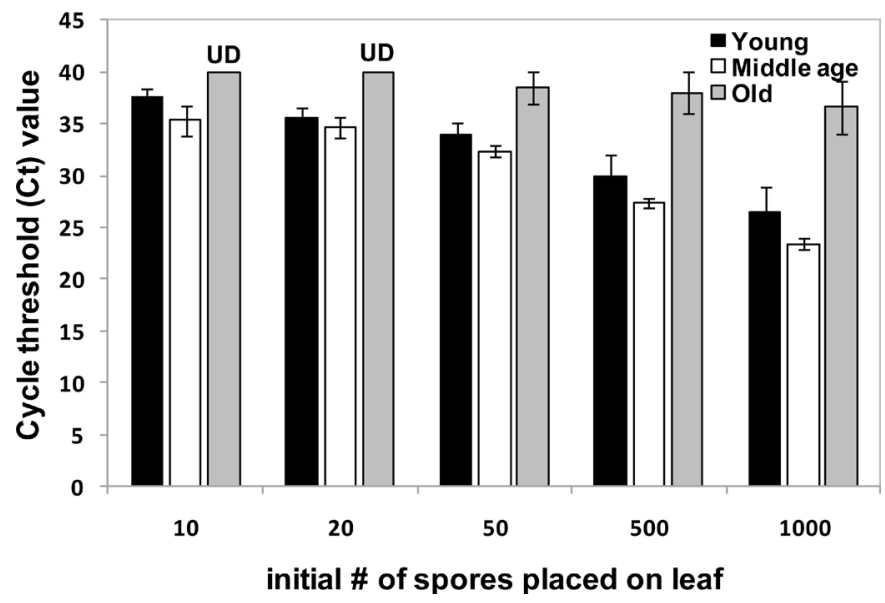

Figure 4. Effect of leaf stage on detection and quantification of Colletotrichum spp. propagule by real time PCR. Equal number of conidia were used to inoculate leaf of different growth stages followed by incubation and extraction of fungal DNA. 
spread from the point of inoculation had any visible disease symptom during the sampling at 60 DAI. Both bioassay (leaf area covered by acervular growth after paraquat treatment) with Paraquat protocol and q-PCR showed higher severity at the point of inoculation compared to samples collected from inside the plot. However, paraquat protocol did not show significant correlation $\left(\mathrm{R}^{2}=0.685 ; P=\right.$ 0.08 ) with severity and distance from point of inoculation indicating a less reliable method for detection of QI. Quantification with real time PCR showed significant correlation $\left(\mathrm{R}^{2}=0.978 ; P \leq 0.05\right)$ with source of inoculum and different distances indicating a better detection method for QI on strawberry foliage (Figure 6).

\section{Discussion}

Detecting quiescent infections in nursery stocks and fruiting fields is very challenging in strawberry production systems that limits growers' ability to implement the best preventive management techniques in an informed integrated pest management (IPM) approach. Optimization of sampling protocol and QI detection methods is essential for advancing diagnostic procedure for anthracnose diseases in strawberry. Assessment of health status of planting stocks by detecting

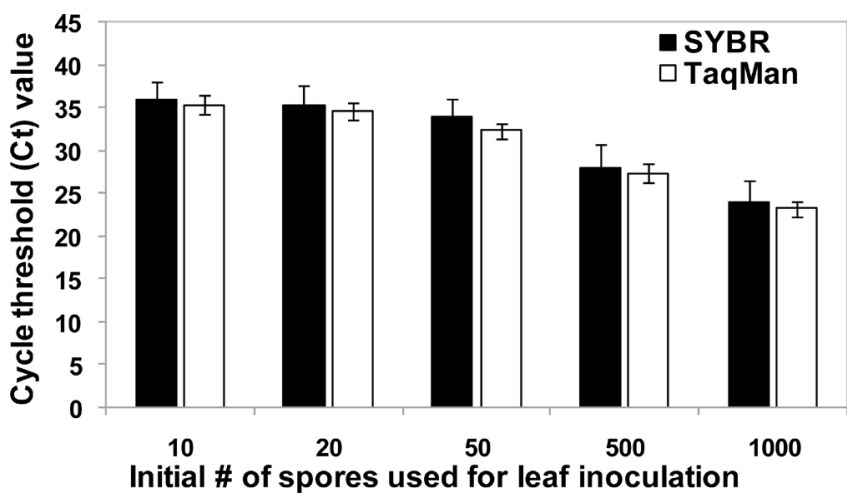

Figure 5. Comparison of TaqMan and SYR green assay with the extracts from known number of conidia $(10-1000)$ placed on pre-selected area of middle aged strawberry leaf in vivo in the greenhouse.
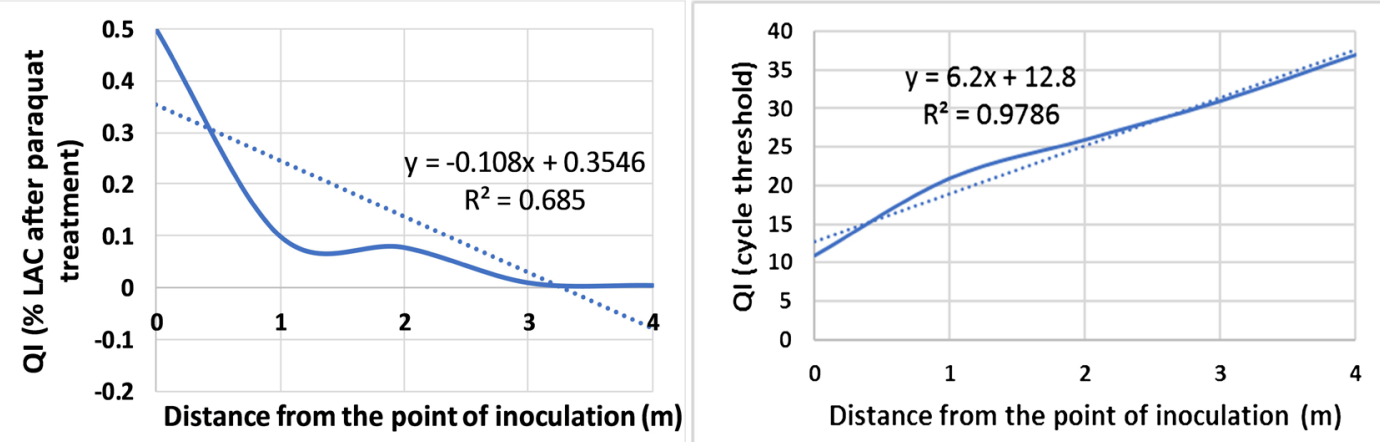

Figure 6. Determination of Colletotrichum spp. dispersal in strawberry field by newly developed real time PCR assay (right) compared with traditional paraquat assay (left); LAC-leaf area covered by acervuli of fungus. 
and quantifying QI should help growers to exclude potentially infected planting stock or disinfest them by treating with effective chemicals. The genus Colletotrichum has undergone frequent taxonomic changes in the past decades with the merging and addition of many species especially under CASC and CGSC [8] [34] as reported in recent studies. These studies were based on multi locus sequencing to differentiate species under the complex. However, our study targeted differentiation of two major species (complex) involved with strawberry anthracnose. We have developed and validated this highly sensitive q-PCR protocol that can detect major species under these two-species complex from foliar quiescent infections. The primers and probe sets developed in this study can detect and quantify extremely low number of propagules from apparently healthy strawberry foliar tissue. It is not uncommon for strawberry foliage to become infected with both species and as such this tool will be equally effective against C.acutatum and C. gloeosporioides detection and quantification. However, recent studies on Colletotricum diagnostics focused on loop-mediated isothermal amplification (LAMP) assay where CASC and CGSC problems occured separately [35] [36].

Real-time PCR primer/probe specificity testing resulted in the amplification of the target Colletotrichum species but none of the non-Colletotrichum isolates. BLAST searches added one other Colletotrichum species such as $C$. viniferum to the list of probable candidates for amplification, that has never been reported as strawberry pathogen and is not supposed to be available on strawberry foliage as quiescent infections. Common cross contamination of strawberry leaves can occur by Botrytis cinerea, Diplocarpon earlianum, Gnomonia comari, Phomopsis obscurans and Mycosphaerella fragariae that commonly grow on paraquat treated dead strawberry leaf tissues even after following a standard surface sterilization assay. Real time PCR with those tissues when used as negative control did not show any amplification indicating the specificity of the tool for Colletotrichum species of major concern to strawberry. The primers and probe set developed in this study provided significant advantages over some of the existing protocols by being more sensitive as the target is located on multi-copy rDNA ITS2 region. Primers and probe sets allowed amplification of both CASC and $C G S C$ templates that can coexist on strawberry foliage in the SE. This protocol can discriminate two groups based on the melting temperature of the amplicons and alleviate the need for multiplexing. It produces comparable results with second-generation dsDNA intercalating dye SYBR green I or third-generation intercalating dye Evagreen which is used in Type-it HRM PCR kit.

The reason of quiescence in strawberry is yet to be proven empirically, however, it is presumably due to the presence of preformed antifungal compounds including polyphenolics which are also known to be a major inhibitor of polymerase in a PCR reaction. Quiescent infection in avocado anthracnose at the green stage was reported to be due to the presence of high concentrations of the preformed antifungal compound 1-acetoxy-2-hydroxy-4-oxo-heneicosa-12,15diene [37], which decreased ten-fold, to subfungitoxic concentrations during 
fruit ripening.

The q-PCR assay consistently yielded higher detection capability than the bioassay or conventional PCR from artificially inoculated plants as well as plants from field experiments. In greenhouse trial with known number of spores, conventional PCR did not produce any amplicons lower than 1000 conidia whereas q-PCR with middle age leaf detected up to 10 conidia. This big difference in sensitivity makes this tool a clear choice over regular PCR for tracking quiescent inoculum in leaf tissue. In phytotron experiment, only $36.5 \%$ petioles showed positive detection by paraquat assay compared to $60.8 \%$ by real time PCR while the differences on leaves were even greater. Positive detection on leaves by bioassay was $65.3 \%$ compared to $89.2 \%$ with real time PCR. These numbers indicate that even in artificially inoculated plants, petioles receive significantly lower amount of inoculum compared to leaf blades. The probability of a false negative is very high for a bioassay if inoculum level is too low to be visible even after multiplication by a paraquat assay. Similar trend was observed in field samples that received inoculum due to a natural spread from inoculated plants set at both ends of the plots. However, average levels of positive detection in field samples were lower than directly inoculated plants in a phytotron. Variability within samplings and positive detection was also higher in the field. This clearly indicates the importance of a special sampling technique to be employed for the assessment of quiescent infection in field grown strawberry either in a nursery or fruiting field. In our leaf stage experiment, we did not get any false negative up to the lowest level of conidia placed on leaf disk indicating the PCR assay is sensitive enough for detecting very low level of quiescent infections when tissues harbor inoculum. Our results indicate that leaf stage can greatly influence the detection and quantification of quiescent infections. Thus, consistency with leaf stage during sampling will play a key role in obtaining meaningful results. The plausible explanation for differences in detection from different leaf stages receiving same initial inoculum in our study could be due to young stage leaf may not be providing enough nutrients for the growth and development of the fungus and old stage leaf may contain higher concentration of inhibitory metabolites that may interfere with PCR amplification. Debode et al. [23] [38] reported a slower establishment of $C$. acutatum on younger leaves compared to older from the leaf inoculation experiment followed by monitoring through microscopic study and DNA extraction. Similar effects of leaf age on disease development were observed with C. gloeosporioides on leaves of Mulva pusilla [39]. While q-PCR is now considered the preferred tool for inspecting plant material from nurseries, planting stocks, fruit production fields, and imported shipments, scientific applications of q-PCR also include tracking the spread of disease through contaminated stock or wild alternate host and population dynamics in a QI of plant. Optimization of sampling method to track foliar QI has not been pursued to the best of our knowledge. However, our initial sampling from a strawberry nursery with a simple random sampling (SRS) followed by assessment and back to positive spots for an adaptive cluster sampling was found to 
produce reliable results (data not shown). Ojiambo and Scherm [40] showed that a computer simulated adaptive cluster sampling consistently produced more precised results for disease incidence compared to SRS when disease was more aggregated in the field. Validation of this tool in strawberry fruiting field for inoculum dispersal showed that detection and quantification of quiescent infection on leaves can be done more accurately with this tool compared with traditional paraquat protocol. Utilization of SYBR green dye will significantly reduce the cost of diagnostics. In a separate assay, Gomes-Ruiz et al. [41] reported the same sensitivity for the Taqman and SYBR Green assay in real-time PCR corroborating our results. The real time primers and probe set designed in this study will provide scientists enough flexibilities of using highly sensitive tool required in disease forecasting experiments based on the presence or absence of inoculum in strawberry foliar tissues, which serves as a potential inoculum source for ripening berries. The ability of these primers and probe set to provide statistically similar results with SYBR green will make it a superior choice for the diagnostic clinics that will seek economically feasible advanced molecular tool for routine use.

\section{Conflicts of Interest}

The authors declare no conflicts of interest regarding the publication of this paper.

\section{References}

[1] Howard, C.M., Maas, J.L., Chandler, C.K. and Albregts, E.E. (1992) Anthracnose of Strawberry Caused by the Colletotrichum Complex in Florida. Plant Disease, 76, 976-981. https://doi.org/10.1094/PD-76-0976

[2] Legard, D.E., Ellis, M., Chandler, C.K. and Price, J.F. (2003) Integrated Management of Strawberry Diseases in Winter Fruit Production Areas. In: Childers, N.F., Ed., The Strawberry: A Book for Growers, Dr. Norman F. Childers Publications, Gainesville, 111-123.

[3] MacKenzie, S.J., Mertely, J.C. and Peres, N.A. (2009) Curative and Protectant Activity of Fungicides for Control of Crown Rot of Strawberry Caused by Colletotrichum gloeosporioides. Plant Disease, 93, 815-820. https://doi.org/10.1094/PDIS-93-8-0815

[4] Eastburn, D.M. and Gubler, W.D. (1990) Strawberry Anthracnose: Detection and Survival of Colletotrichum acutatum in Soil. Plant Disease, 74, 161-163. https://doi.org/10.1094/PD-74-0161

[5] Freeman, S., Horowitz, S. and Sharon, A. (2001) Pathogenic and Nonpathogenic Lifestyles in Colletotrichum acutatum from Strawberry and Other Plants. Phytopathology, 91, 986-992. https://doi.org/10.1094/PHYTO.2001.91.10.986

[6] Leandro, L.F.S., Gleason, M.L., Nutter Jr., F.W., Wegulo, S.N. and Dixon, P.M. (2001) Germination and Sporulation of Colletotrichum acutatum on Symptomless Strawberry Leaves. Phytopathology, 91, 659-664. https://doi.org/10.1094/PHYTO.2001.91.7.659

[7] McInnes, T.B., Black, L.L. and Gatti Jr., J.M. (1992) Disease-Free Plants for Management of Strawberry Anthracnose Crown rot. Plant Disease, 76, 260-264. 
https://doi.org/10.1094/PD-76-0260

[8] Weir, B.S., Johnston, P.R. and Damm, U. (2012) The Colletotrichum gloeosporioides Species Complex. Studies in Mycology, 73, 115-180.

https://doi.org/10.3114/sim0011

[9] Parikka, P. and Lemmetty, A. (2004) Tracing Quiescent Infection of Colletotrichum acutatum on Strawberry by PCR. European Journal of Plant Pathology, 110, 393-398. https://doi.org/10.1023/B:EJPP.0000021073.67137.d2

[10] Mertely, J.C. and Legard, D.E. (2004) Detection, Isolation, and Pathogenicity of Colletotrichum spp. from Strawberry Petioles. Plant Disease, 88, 407-412. https://doi.org/10.1094/PDIS.2004.88.4.407

[11] Nam, M.H., Lee, I.H., Kwon, K.H. and Kim, H.G. (2004) Significance and Detection of Quiescent Infection of Colletotrichum gloeosporioides on Strawberry. Korean Journal of Horticultural Science and Technology, 22, 294-297.

[12] Ishikawa, S. (2003) Method to Diagnose Quiescent Infection by Glomerella cingulata in Strawberry Plants Using Ethanol. Journal of General Plant Pathology, 69, 372-377. https://doi.org/10.1007/s10327-003-0071-x

[13] Martinez-Culebras, P.V., Querol, A., Suarez-Fernandez, M.B., Garcia-Lopez, M.D. and Barrio, E. (2003) Phylogenetic Relationships among Colletotrichum Pathogens of Strawberry and Design of PCR Primers for Their Identification. Journal of Phytopathology, 151, 135-143. https://doi.org/10.1046/j.1439-0434.2003.00694.x

[14] Martinez-Culebras, P.V., Barrio, E., Garcia-Lopez, M.D. and Querol, A. (2000) Identification of Colletotrichum Species Responsible for Anthracnose of Strawberry Based on the Internal Transcribed Spacers of the Ribosomal Region. FEMS Microbiology Letters, 189, 97-101. https://doi.org/10.1016/S0378-1097(00)00260-3

[15] Rodriguez, R.J. and Yoder, O.C. (1991) A Family of Conserved Repetitive DNA Elements from the Fungal Plant Pathogen Glomerella cingulata (Colletotrichum lindemuthianum). Experimental Mycology, 15, 232-242. https://doi.org/10.1016/0147-5975(91)90025-9

[16] Sreenivasaprasad, S., Sharada, K., Brown, A.E. and Mills, P.R. (1996) PCR-Based Detection of Colletotrichum acutatum on Strawberry. Plant Pathology, 45, 650-655. https://doi.org/10.1046/j.1365-3059.1996.d01-3.x

[17] Freeman, S. and Rodriguez, R.J. (1995) Differentiation of Colletotrichum Species Responsible for Anthracnose of Strawberry by Arbitrarily Primed PCR. Mycological Research, 99, 501-504. https://doi.org/10.1016/S0953-7562(09)80653-9

[18] Bonde, M.R., Peterson, G.L. and Maas, J.L. (1991) Isozyme Comparisons for Identification of Colletotrichum Species Pathogenic to Strawberry. Phytopathology, 81, 1523-1528. https://doi.org/10.1094/Phyto-81-1523

[19] Buddie, A.G., Martinez-Culebras, P., Bridge, P.D., Garcia, M.D., Querol, A., Cannon, P.F. and Monte, E. (1999) Molecular Characterization of Colletotrichum Strains Derived from Strawberry. Mycological Research, 103, 385-394.

https://doi.org/10.1017/S0953756298007254

[20] Correll, J.C., Rhoads, D.D. and Guerber, J.C. (1993) Examination of Mitochondrial DNA Restriction Fragment Length Polymorphisms, DNA Fingerprints, and Randomly Amplified Polymorphic DNA of Colletotrichum orbiculare. Phytopathology, 83, 1199-1204. https://doi.org/10.1094/Phyto-83-1199

[21] Cawthon, D., Dyson, W., Correll, J.C. and Rhoads, D.D. (1994) RAPD Isolation of Fingerprint Probes for Analysis of Colletotrichum Species. Phytopathology, 84, 1124.

[22] Martinez-Culebras, P.V., Barrio, E., Suarez-Fernandez, M.B., Garcia-Lopez, M.D. 
and Querol, A. (2002) RAPD Analysis of Colletotrichum Species Isolated from Strawberry and the Design of Specific Primers for the Identification of $C$. fragariae. Journal of Phytopathology, 150, 680-686. https://doi.org/10.1046/j.1439-0434.2002.00823.x

[23] Debode, J., Van Hemelrijck, W., Baeyen, S., Creemers, P., Heungens, K. and Maes, M. (2009) Quantitative Detection and Monitoring of Colletotrichum acutatum in Strawberry Leaves Using Real-Time PCR. Plant Pathology, 58, 504-514. https://doi.org/10.1111/j.1365-3059.2008.01987.x

[24] Denoyes-Rothan, B., Guérin, G., Délye, C., Smith, B., Minz, D., Maymon, M. and Freeman, S. (2003) Genetic Diversity and Pathogenic Variability among Isolates of Colletotrichum Species from Strawberry. Phytopathology, 93, 219-228. https://doi.org/10.1094/PHYTO.2003.93.2.219

[25] Tian, B., Rentz, S.S., Gorman1, G.S., Rogers, T. and Page, J.G. (2004) Comparison of Real-Time PCR Assay Methods in Detection and Quantitation of $\beta$-Actin Genes in Mouse Tissues. Preclinica, 2, 214-220.

[26] Bilodeau, G.J., Lévesque, C.A., de Cock, A.W.A.M., Duchaine, C., Brière, S., Uribe, P., Martin, F.N. and Hamelin, R.C. (2007) Molecular Detection of Phytophthora ramorum by Real-Time Polymerase Chain Reaction Using TaqMan, SYBR Green, and Molecular Beacons. Phytopathology, 97, 632-642.

https://doi.org/10.1094/PHYTO-97-5-0632

[27] Garrido, C., Carbú, M., Fernández-Acero, F.J., Boonham, N., Colyer, A., Cantoral, J.M. and Budge, G. (2009) Development of Assays for Detection of Colletotrichum acutatum and Monitoring of Strawberry Anthracnose Using Real-Time PCR. Plant Pathology, 58, 43-51. https://doi.org/10.1111/j.1365-3059.2008.01933.x

[28] Louws, F.J. (2010) Anthracnose Fruit Rot of Strawberry. NC State Extension Fact Sheet. https://content.ces.ncsu.edu/anthracnose-fruit-rot-of-strawberry

[29] McGlauflin, M.T., Smith, M.J., Wang, J.T., Young, S.F., Chen, N., Lee, Y.C., Pascal, C., Seeb, L.W., Stevens, J. and Seeb, J.E. (2010) High-Resolution Melting Analysis for the Discovery of Novel Single-Nucleotide Polymorphisms in Rainbow and Cutthroat Trout for Species Identification. Transactions of the American Fisheries Society, 139, 676-684. https://doi.org/10.1577/T09-103.1

[30] Varga, A. and James, D. (2006) Real-Time RT-PCR and SYBR Green I Melting Curve Analysis for the Identification of Plum Pox Virus Strains C, EA, and W: Effect of Amplicon Size, Melt Rate, and Dye Translocation. Journal of Virological Methods, 132, 146-153. https://doi.org/10.1016/j.jviromet.2005.10.004

[31] Rahman, M., Carnes, M.E. and Louws, F.J. (2009) Real-Time PCR Systems Aid in Quantitative Detection of Colletotrichum spp. in Spatial Dispersal Studies of Strawberry Anthracnose. Phytopathology, 99, S107.

[32] Rahman, M. and Louws, F.J. (2010) Quantification of Colletotrichum acutatum Quiescent Infection on Strawberry Foliage by Real-Time PCR to Predict Field Anthracnose Incidence. California Strawberry Commission Annual Production Research Report 2009-2010, Chapter 18.

http://www.calstrawberry.com/Portals/2/Reports/Research\%20Reports/Annual\%20Produ ction\%20Research\%20Reports/Annual\%20Production\%20Research\%20Reports\%202009 12009-10_Chapter18_FrankLouws_Cacutatum.pdf?ver=2018-03-02-141720-273

[33] Applied Biosystems (2006) Real-Time PCR vs. Traditional PCR. http://www.appliedbiosystems.com/support/tutorials/pdf/rtpcr_vs_tradpcr.pdf

[34] Damm, U., Cannon, P.F., Woudenberg, J.H.C. and Crous, P.W. (2012) The Colletotrichum acutatum Species Complex. Studies in Mycology, 73, 37-113. 
https://doi.org/10.3114/sim0010

[35] Zhang, X., Harrington, T.C., Batzer, J.C., Kubota, R., Peres, N.A. and Gleason, M.L. (2016) Detection of Colletotrichum acutatum Sensu Lato on Strawberry by LoopMediated Isothermal Amplification. Plant Disease, 100, 1804-1812. https://doi.org/10.1094/PDIS-09-15-1013-RE

[36] Wang, S., Ye, W., Tian, Q., Dong, S. and Zheng, X. (2017) Rapid Detection of Colletotrichum gloeosporioides Using a Loop-Mediated Isothermal Amplification Assay. Australasian Plant Pathology, 46, 493-498. https://doi.org/10.1007/s13313-017-0511-2

[37] Prusky, D., Keen, N.T., Sims, J.J. and Midland, S.L. (1982) Possible Involvement of an Antifungal Diene in the Latency of Colletotrichum gloeosporioides on Unripe Avocado Fruits. Phytopathology, 72, 1578-1582.

https://doi.org/10.1094/Phyto-72-1578

[38] Debode, J., Van Hemelrijck, W., Xu, X.M., Maes, M., Creemers, P. and Heungen, K. (2015) Latent Entry and Spread of Colletotrichum acutatum (Species Complex) in Strawberry Fields. Plant Pathology, 64, 385-395. https://doi.org/10.1111/ppa.12247

[39] Wei, Y.D., Byer, K.N. and Goodwin, P.H. (1997) Hemibiotrophic Infection of Round-Leaved Mallow by Colletotrichum gloeosporioides f. sp. malvae in Relation to Leaf Senescence and Reducing Reagents. Mycological Research, 101, 357-364. https://doi.org/10.1017/S0953756296002651

[40] Ojiambo, P.S. and Scherm, H. (2010) Efficiency of Adaptive Cluster Sampling for Estimating Plant Disease Incidence. Phytopathology, 100, 663-670. https://doi.org/10.1094/PHYTO-100-7-0663

[41] Gomes-Ruiz, A.C., Nascimento, R.T., Paula, S.O. and Benedito, A.L.F. (2006) SYBR Green and TaqMan Real-Time PCR Assays Are Equivalent for the Diagnosis of Dengue Virus Type 3 Infections. Journal of Medical Virology, 78, 760-763. https://doi.org/10.1002/jmv.20620 